\title{
Paideusis
}

\section{Dewey and Russell: In Search of Common Ground}

\section{William Hare}

Volume 10, Number 2, 1997

URI: https://id.erudit.org/iderudit/1073181ar

DOI: https://doi.org/10.7202/1073181ar

See table of contents

Publisher(s)

Canadian Philosophy of Education Society

ISSN

0838-4517 (print)

1916-0348 (digital)

Explore this journal

Cite this article

Hare, W. (1997). Dewey and Russell: In Search of Common Ground. Paideusis, 10(2), 25-31. https://doi.org/10.7202/1073181ar

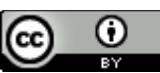

This document is protected by copyright law. Use of the services of Erudit (including reproduction) is subject to its terms and conditions, which can be viewed online.

https://apropos.erudit.org/en/users/policy-on-use/
This article is disseminated and preserved by Érudit.

Érudit is a non-profit inter-university consortium of the Université de Montréal, Université Laval, and the Université du Québec à Montréal. Its mission is to promote and disseminate research.

https://www.erudit.org/en/ 


\title{
Dewey and Russell: In Search of Common Ground
}

\author{
William Hare, Mount St. Vincent University
}

\section{Response to Michael Rockler}

Michael Rockler has attempted to assess the contributions of Bertrand Russell and John Dewey to our understanding of democracy. They are two of the most prolific philosophers who have ever lived and their thoughts on this highly contestable concept are scattered through numerous books and essays written over a period of several decades. Rockler has set himself an heroic, some might say, impossible task. I tend to agree with those who believe that even impossible tasks are, nevertheless, worth attempting for what we can learn and achieve in the process, ${ }_{1}$ and $I$ applaud Rockler for taking on this challenging work. His thesis essentially is that Dewey fares rather badly in the comparison on several counts: being willing to sacrifice individual identity for the sake of social coherence; being naive and unsophisticated about the limits of democracy and the danger of totalitarianism; being too ready to apply democratic ideas to schooling and education, leading to schools without standards; and thinking that truth itself is nothing more than majority belief. This is a very large agenda indeed. As an admirer of Russell, I suspect that Rockler might agree with him regarding his own thesis that "truth is for the gods; from our human point of view, it is an ideal towards which we can approximate, but which we cannot hope to reach." 2 Certainly, in a brief commentary, it would be absurd for me to attempt a refutation, and I shall limit myself to raising some questions in an attempt to continue the conversation. Not everyone would agree that these charges against Dewey, even if true, amount to faults, but I will mainly be concerned to ask how far Rockler's reading of Dewey is plausible.

Let me begin with the contrast suggested between the way in which Russell applies the notion of democracy to schools and Dewey's approach. Russell believed that education should be democratic in at least the sense that equality of opportunity for every student is one central ideal. He is careful to insist, however, that this democratic ideal does not mean, as Rockler reminds us, that "a dead level of uniformity" is demanded. Apart from differences in ability, it is impossible that everyone should be taught by the few best teachers. ${ }^{3}$ Rockler suggests that Dewey would probably take issue with Russell on this point. Here I am simply not persuaded, and it may be significant that Rockler has no telling quotation from Dewey to support his suspicion. There is, in fact, much counterevidence. Certainly, Dewey did not subscribe to the view that the intelligence needed to guide collective action was confined to a superior few; at the same time, however, he was careful to point out that belief in equality as an element of democracy did not entail belief in equality of natural endowments:

In short, each one is equally an individual and entitled to equal opportunity of development of his own capacities, be they large or small .... The very fact of natural and psychological inequality is all the more reason for establishing by law of equality of opportunity, since otherwise the former becomes a means of oppression of the less gifted. ${ }^{4}$ 
In language reminiscent of Russell's remark, Dewey comments elsewhere that there is "an inclination to propound aims which are so uniform as to neglect the specific powers and requirements of an individual." I am not convinced, therefore, that Dewey would have been any happier than Russell with a dead level of uniformity in the outcomes of education.

By contrast with Russell's ringing denunciation of what he saw-and what many others have seen-as Plato's leanings towards totalitarianism, ${ }^{6}$ Dewey is presented as having revered Plato even though a creator of a fascist political system. Thus, by the greatest irony, the philosopher of democracy proves to be unduly sympathetic towards an archenemy of democratic ideals. I would temper this rather harsh assessment of Dewey in several ways. First, it is clear, I think, that what Dewey admires in Plato is his general recognition of the "educational significance of social arrangements" and of the way in which these arrangements, in turn, depend upon the way in which children are educated, rather than Plato's specific proposals, such as censorship, which Dewey deplored ("Falsities come out in the wash of experience as dirt comes out in soap and water."7) Second, having acknowledged a certain strength in Plato's general approach, Dewey immediately proceeds to condemn Plato's argument as not only superficial but "in bondage to static ideals." With heavy irony, Dewey speaks of Plato awaiting some "happy accident" which would unite philosophic wisdom and political power. 8 I do not find this tone reverential. Third, and more generally, I think there is ample evidence in many places in Dewey's writings that he had no truck with totalitarianism. Democratic ends need democratic methods, Dewey remarked in rejecting the idea that totalitarianism was needed to fight totalitarianism, ${ }^{9}$ a position very much akin to Russell's view that we do not need fanaticism to defeat fanaticism. ${ }^{10}$

Rockler would seem to agree with what he takes to be Russell's criticism of pragmatism, that it imports political ideals into the realm of epistemology-inappropriately insofar as they are meant to provide a touchstone of truth or knowledge rather than to suggest principles to govern inquiry-making, as Russell puts it, "the majority, for practical purposes, the arbiters of what to believe."11 Rockler asserts that Dewey views knowledge as constructed, not objective, and the construction itself is essentially a matter of majority consensus. Some will feel that Dewey's conception of knowledge as constructed puts him on the side of the angels, but I shall have to leave that substantive issue aside. My first point, inspired by Dewey, would be that the dichotomy between what is constructed and what is objective is a false one, since it is clearly possible to distinguish constructions as illusory or veridical. Nevertheless, did Dewey view the construction of knowledge, and the determination of truth, as a matter of majority consensus, and in this way misapply democratic ideals? I cannot myself reconcile that suggestion with Dewey's general outlook. On that account, what could Dewey mean by his reference to a wrong view getting general acceptance? How could he agree with Locke, as he does, that one chief way in which thought goes wrong is when it gives assent to "the common received opinions"? One would have thought, on the majority consensus view, that that is exactly how it would go right. Again, on the supposed view, why would Dewey say that the difference in the adequacy of different cases of thinking is due to "the care and thoroughness with which the operations of critical summoning and weighing of evidence are performed?",12 
The conclusion that Dewey is willing to sacrifice individual identity for an "organic union of individuals" is, perhaps, the most difficult point to respond to in any satisfactory way in a brief comment. Others, too, have found Dewey's position decidedly illiberal in this area, ${ }^{13}$ and certainly a strong case can be made for the thesis that Dewey gave pride of place to fraternal solidarity rather than to individualism in his conception of democracy-a case which would strike one as absurd were it made about Russell. Nevertheless, a few observations are in order. First, I would not place any weight on the fact that Dewey's terminology turns up in subsequent fascist writings. Dewey himself reminds us that "the slogans of the liberalism of one period often become the bulwarks of reaction in a subsequent era." Second, it is worth noting that, as early as 1897 in My Pedagogic Creed, Dewey claimed that his conception of education had "due regard for both the individualistic and socialistic ideals,"14 much as Russell declared that he supported a "due proportion" among competing theories with respect to the debate between individuality and citizenship. ${ }^{15}$ Again, in a talk on the occasion of his eightieth birthday, Dewey described the democratic faith as belief in equal opportunity to develop whatever gifts one has: "It is the belief in the capacity of every person to lead his own life free from coercion and imposition by others provided right conditions are supplied."16 This would seem to allow for the free development of individual interests. He added: "To co-operate by giving differences a chance to show themselves because of the belief that the expression of differences is not only a right of the other persons but is a means of enriching one's own life experience is inherent in the democratic personal way of life."1

\section{Response to John Novak}

It will be evident from these comments that I am generally sympathetic to John Novak's defence of Dewey. Novak begins by reviewing his recent debates with Michael Rockler in which the respective merits of Dewey and Russell in connection with various themes have been examined, and some of these ideas have surfaced already in my earlier comments. Concerning the eight "main charges," let me just add an additional word about his point 7 , the accusation that Dewey did not focus heavily on the acquisition of knowledge. Hirsch makes a similar claim in Cultural Literacy, ${ }^{18}$ and Alan Ryan remarks in his 1995 book on Dewey that "Dewey insists that acquiring information is incidental to thinking as problem solving." 19 It is unfortunate that that observation is somewhat ambiguous, for "incidental" might suggest (a) occurring in connection with something else, or (b) occurring as a less important part of something else. It is the first of these which is correct, and what Ryan intends, I believe, because Dewey wanted the acquisition of information to be what he called an "integral portion" of the training of thought ${ }^{20}$ There is no suggestion, however, that information is relatively unimportant. Thinking, said Dewey, cannot go in in a vacuum. ${ }^{21}$ Dewey's criticisms of information consistently concern the way in which it is acquired and to what end. About information intelligently held, Dewey spoke in glowing terms: "To be informed is to be posted; it is to have at command the subject matter needed for an effective dealing with a problem, and for giving added significance to the search for solution and to the solution itself." 22 This is not to say that Dewey always lived 
up to this view in his own practice; apparently, some of the teachers at the so-called "Dewey school" believed that insufficient attention was paid to information. ${ }^{23}$ Such deficiencies in practice, I believe, underline the truth of John Novak's observation that Deweyan democracy is not easy.

Rather than pursue a debate which pits Dewey against Russell, Novak attempts to foster understanding between supporters on each side. He sketches Dewey's position on a number of key issues, and asks where Russell stands with respect to them. The spirit in which these are raised is, I take it, exploratory rather than accusatory, and they are intended, I think, to help answer one final, general question: Can Russellians and Deweyans work together for the development of a democratic culture? I hope my comments thus far do something to show that there is more common ground than is sometimes recognized when specific differences are emphasized. Novak reminds us, in a section on "Deweyan democracy," that Dewey saw democracy as an ethical ideal, a way of life involving cognitive and moral virtues. Democracy is to be pursued and created, and the pursuit rests on the faith that human intelligence can profit from experience to create a better future, despite the seemingly insurmountable and intractable problems which surround us. Novak is right that Dewey does not offer us precise answers or concrete programs. As Alan Ryan puts it, Dewey's theory "is not a set of instructions but an account of the things we need to take into account when deciding what to do."24

Surely, Russell would applaud this general conception whatever his differences from Dewey with respect to matters of emphasis, perceptions of urgency, or decisions about strategy might be. Bring to mind the short, moving essay Russell published in 1941 under the title "A philosophy for you in these times," where he set out to respond to the feeling of hopelessness experienced by so many during the war: "What is needed is something in the nature of religion, not in any dogmatic sense, but as a source of serious and determined effort towards something better than the present."25 Russell went on to say that "democracy, for example, is not like something that can be kept in a safe; it must be a living force, an aspiration as well as something partly possessed."26 Of the virtues centrally connected with the pursuit and defence of democracy, Russell mentioned imagination, courage, tolerance, and truthfulness. Like Dewey, Russell wanted to better the quality of human experience and shared life, and he typically singled out education as crucially important in this respect:

\footnotetext{
... in education you will have to stress that mankind is one family with common interests. That therefore co-operation is more important than competition, and that to love your neighbour is not only a moral duty nominally inculcated by the churches, but is also much the wisest policy from the point of view of your own happiness." 27
}

Concerning Novak's five specific questions for Russellians, with respect to Russell's views on evolution, mind and its relation to society, human beings as social, creative responses to pluralism, and the relationship between his philosophy and political views, it is obviously not possible to respond to these adequately in this context. In terms of the broad strokes drawn by Novak, however, I see nothing to undermine the positive answer I have suggested to his general question about Russellian/Deweyan co-operation. I shall offer five alltoo-brief responses to Novak's questions, taken directly from Russell, which are all rooted in Russell's commitment to open-minded and disinterested inquiry. 


\section{Five questions:}

1. To what extent does Russell's philosophy connect with evolution? One answer concerns the way in which reflection on the theory of evolution can help to promote certain emerging and vitally important attitudes: "Under the influence of Darwinism the scientific attitude ... has now become fairly common .... [It] involves a sweeping away of all other desires in the interests of the desire to know ... in philosophy this attitude of mind has not as yet been achieved." 28

2. How does Russell's conception of mind connect with nature and society? Further to the point just made, we might note Russell's rejection of what he called evolutionism, the idea that the world was inexorably heading towards a glorious result: "In the world of values nature in itself is neutral, neither good nor bad, deserving of neither admiration nor censure . . . It is for us to determine the good life, not for nature-not even nature personified as God."29 Russell observed that "impartiality of contemplation is, in the intellectual sphere, that very same virtue of disinterestedness which, in the sphere of action, appears as justice and unselfishness." 30

3. For Russell, in what sense are humans social? We might recall Russell's view that humankind is one family with common interests: "It is not possible to isolate ourselves sufficiently to make even our own personal happiness secure .... If I had no hopes for the world, I could not be satisfied to shut myself up in a little private circle .... Everyone agrees that we should not be selfcentred, relating everything that happens to ourselves, making ourselves the centre of the universe." 31

4. How does Russell suggest we can creatively deal with the tensions of a pluralistic social life? One answer lies in a more open and diverse curriculum: "The poetry, folk-lore and history of the country from which they (i.e., immigrants) come should be kept alive in their memory .... It is a misunderstanding of democracy that it sanctions, or even proclaims, the unlimited tyranny of the majority." 32 Russell shared Dewey's belief about the importance of intelligence and creativity in decision-making: "There seems scarcely any limit to what could be done in the way of producing a good world, if only men would use science wisely.",33

5. How is Russell's view of philosophy connected to other parts of life, particularly his politics? Russell pointed out the need to carry over the scientific spirit into philosophy, which would challenge dogmatism, ideology, fanaticism and authoritarianism: "Scientific theories are accepted as useful hypotheses to suggest further research . . . . but no sensible person regards them as immutably perfect. In the sphere of practical politics, this intellectual attitude has important consequences." 34 
If not quite the fraternal, philosophical twins depicted by John L. McKenney some years ago, ${ }^{35}$ we might at least say, given Russell's own remark that he and Dewey were in almost complete agreement on many issues, ${ }^{36}$ that, with respect to the issues discussed here, they are not-too-distant cousins.

\section{Notes}

${ }^{1}$ It is not clear that Dewey would agree, for in one place he observes that it is always stupid to attempt the impossible! See "Individuality and Freedom," reprinted in Joseph Ratner (Ed.), Intelligence in the Modern World: John Dewey's Philosophy (New York: Random House, 1939), 624.

2Bertrand Russell, "Freedom versus Authority in Education," in Russell, Sceptical Essays (London: Unwin, 1977), 149. (Originally published, 1928.)

${ }^{3}$ Bertrand Russell, On Education (London: Unwin, 1971), 14. (Originally published, 1926.)

4John Dewey, "Democracy and Educational Administration," in Dewey, Problems of Men (New York: Philosophical Library, 1946), 60.

5 John Dewey, Democracy and Education (New York: The Free Press, 1966), 108. (Originally published, 1916.)

${ }^{6}$ Not all commentators accept this interpretation. See, for example, Robin Barrow, Plato, Utilitarianism and Education (London: Routledge and Kegan Paul, 1975).

7Dewey, "The basic values and loyalties of democracy," reprinted in Debra Morris and Ian Shapiro (eds.), John Dewey: The Political Writings (Indianapolis, IN: Hackett, 1993), 208. (Essay originally published, 1941.)

${ }^{8}$ Dewey, Democracy and Education, op. cit., 91.

${ }^{9}$ Dewey, "Democratic ends need democratic methods for their realization," reprinted in Morris and Shapiro (Eds.), John Dewey: The Political Writings, op. cit., 205-6. (Essay originally published, 1939.)

${ }^{10}$ Bertrand Russell, "Why fanaticism brings defeat," The Listener, September 23, 1948, 452-53.

${ }^{11}$ Bertrand Russell, History of Western Philosophy (2nd ed.), (London: George Allen and Unwin, 1961), 94. (Originally published, 1946.)

${ }^{12}$ All of these questions refer to points made by Dewey in How We Think (2nd ed.) (Boston: D.C. Heath, 1933), ch. 2.

${ }^{13}$ Eamonn Callan, "Education for democracy: Dewey's illiberal philosophy of education," Educational Theory, 31(2), 1981, 167-75.

14 John Dewey, "My pedagogic creed," reprinted in Reginald D. Archambault (Ed.), John Dewey on Education: Selected Writings (New York: Random House, 1964), 437.

${ }^{15}$ Bertrand Russell, Education and the Social Order (London: Unwin, 1977), 21. (Originally published, 1932.)

"John Dewey, "Creative democracy-The task before us," in Max H. Fisch (Ed.), Classic American Philosophers (Englewood Cliffs, NJ: Prentice-Hall, 1951), 392.

${ }^{17}$ Ibid., 393. 
Xv.

${ }^{18}$ E.D. Hirsch, Jr., Cultural Literacy (New York: Random House, 1988),

${ }^{19}$ Alan Ryan, John Dewey and the High Tide of American Liberalism (New York: W.W. Norton, 1995), 145.

${ }^{20}$ This was clearly stated in the first edition of How We Think (Buffalo, NY: Prometheus, 1991), 52. (Originally published, 1910.)

${ }^{21}$ I discuss this further in "Content and criticism: The aims of schooling," Journal of Philosophy of Education, 29(1), 1995, 47-60. Reprinted in Inquiry: Critical Thinking Across the Disciplines, 14(3), 1995, 13-27.

22 John Dewey, Democracy and Education, op. cit., 188.

${ }^{23}$ Even Dewey's admirers have conceded that his own practice as a teacher hardly accorded with his pedagogical views. See Sidney Hook, Out of Step (New York: Harper and Row, 1987), 82. For the views of some of the teachers at the Laboratory School, see Jerald Katch, "John Dewey's School," in Kathe Jervis and Carole Montag (Eds.), Progressive Education for the 1900s (New York: Teachers College Press, 1991), 61-70.

${ }^{24}$ Ryan, op. cit., 99.

${ }^{25}$ The essay was published in The Reader's Digest, (October)1941, 5-7. I have quoted from the original version of the essay which was subsequently published as "On keeping a wide horizon," Russell, The Journal of the Bertrand Russell Archives, 33-4, 1979, 8.

1979, 8. It is now reprinted in The Collected Papers of Bertrand Russell, vol. 10 (London: Routledge, 1996), 452-7.

${ }^{26}$ Op. cit., 11.

${ }^{27}$ Bertrand Russell Speaks His Mind (New York: Bard Books, 1960), 142. A transcript of an interview with Woodrow Wyatt.

${ }^{28}$ Bertrand Russell, "The place of science in a liberal education," in Mysticism and Logic (Harmondsworth: Penguin Books, 1943), 47-8. (Collection originally published, 1918.)

${ }^{29}$ Bertrand Russell, "What I believe," in Why I Am Not a Christian (New York: Simon and Schuster, 1957), 55-6. cit., 27.

${ }^{30}$ Bertrand Russell, "Mysticism and logic," in Mysticism and Logic, op.

${ }^{31}$ Bertrand Russell, "On keeping a wide horizon," op. cit., 6-7.

32 Bertrand Russell, "The problem of minorities," in Barry Feinberg and Ronald Kasrils, Bertrand Russell's America, Vol. 1, 1896-1945 (London: George Allen and Unwin, 1973), 326.

${ }^{33}$ Bertrand Russell, "What I believe," in Russell, Why I Am Not a Christian, op. cit., 83.

${ }^{34}$ Bertrand Russell, "Philosophy and politics," in Unpopular Essays (London: George Allen and Unwin, 1950), 30.

${ }^{35}$ John L. McKenney, "Dewey and Russell: Fraternal twins in philosophy," Educational Theory, 9(1), 1959, 2430. 774.

${ }^{36}$ Bertrand Russell, History of Western Philosophy (2nd ed.), op. cit., 